\title{
Factors Affecting Cash Holding in Indonesia Manufacturing Companies
}

\author{
Dewi Maya Sari ${ }^{1 *}$, Dara Angreka Soufyan ${ }^{2)}$, Ainul Ridha ${ }^{3)}$ \\ ${ }^{1 *)}$ Public Sector Accounting Study Program, Politeknik Aceh \\ Jalan Politeknik Aceh No. 1, Pango Raya, Banda Aceh, Indonesia, 23119 \\ ${ }^{2)}$ Accounting Study Program, Faculty of Economics, University of Teuku Umar \\ Jalan Alue Peunyareng, Meureubo, Aceh Barat, Indonesia, 23681 \\ 3) Accounting Study Program, Sekolah Tinggi Ilmu Ekonomi Sabang \\ Jalan Prada Utama No.15, Peurada, Banda Aceh, Indonesia, 24415 \\ E-mail:dewi@politeknikaceh.ac.id ${ }^{1 *}$
}

\begin{abstract}
This study aims to analyze the effect of leverage, net working capital, and firm size on cash holding using panel data regression method based on data on the financial statements of manufacturing companies available on the Indonesia Stock Exchange from 2012 to 2014. Testing with the Chow test states that the data regression model the panel used is the common effect. The results of this study indicate that cash holding is positively influenced by leverage, net working capital, and firm size. The greater the leverage, net working capital, and company size will increase the availability of cash in the company.
\end{abstract}

Keywords: Cash Holding; Leverage; Net Working Capital; Firm Size

\section{INTRODUCTION}

Both effective and efficient cash management can be seen from the firm's ability to ensure sufficient cash that is available to meet its needs. One form of firm cash management is to hold cash at the optimal point (cash holding). Holding large amounts of cash will provide benefits, one of them is the savings in conversion costs to cash so that if there is a sudden need for cash, the company can immediately fulfill it. However, holding large amounts of cash also has a disadvantage where the company loses the opportunity to earn additional profits due to idle funds, which is detrimental to shareholders because the rate of return is below what it should be. There are several motives in cash holding, namely transaction motives, speculative motives, and prudential motives. The three motives will determine the firm's reasons for conducting a cash holding (Null and Pathak, 2019).

Cash becomes very important during a crisis like the one that occurred at the end of 2007. The financial crisis that occurred at that time resulted in a credit crisis. The impact of the crisis had profound and sustained effects on the operations of firms around the world. Firms with sufficient cash balances could escape the crisis by entering the increasingly expensive and limited capital market (Subramaniam, Tang, Yue, and Zhou, 2011). By entering the capital market, firms can still operate amid the current crisis, things that 
companies with petty cash balances cannot do because of the limited funds they have.

Cash holding is characterized as cash on hand or accessible for interest in actual resources and conveyance to investors (Gill and Shah, 2012). Accordingly, cash holding is viewed as money or cash equivalents that can be handily changed over into money. In addition, cash holding is a very obvious option chosen by firms. However, the determination of the firm's cash holding rate must be decided wisely because one of the significant financial decisions that a manager must make. If there is an inflow of money, a manager can choose to circulate it to investors as dividends. or to buy back shares, invest it, or perhaps save it to meet the needs of the firm in the future (Ginglinger and Saddour, 2007).

There are a few factors that can affect corporate cash holding. The first factor estimated to affect the cash holding is leverage. Leverage is a comparison between assets and debt owed by a firm that illustrates how much the company's assets are financed by debt. Firms with a high level of leverage are considered unsolvable because the total debt is bigger than their total assets. If leverage is used as a proxy for a firm's ability to issue debt, it is estimated that there will be a positive relationship between leverage and cash holding.

The second factor that is estimated to affect cash holding is net working capital. Networking capital is a proxy for investment in current assets that can be used as a substitute for firm cash (Ogundipe, Lawrencia, and Ogundipe, 2012). This situation happens as it is easy to convert it into cash when the firm needs it. Networking capital can act as a good cash substitution (Bigelli and Vidal, 2009). The bigger the networking capital a firm has, the smaller its cash balance. Research conducted by (Kim, Kim, and Woods, 2011) found that organizations with enormous net working capital by and large hold limited quantities of money. Consequently, the connection between net working capital and cash holding is negative.

The third factor that is estimated to affect the company's cash holding is firm size. The size of a firm can be seen from the number of assets the company has, the level of sales that occurred in a certain period, and market capitalization. The bigger the number of assets a firm has, the bigger the capital invested in the company, and the more sales a company can generate, the higher the circulation of money. According to the trade-off theory, fundraising is cheaper for larger firms expecting to hope less cash. The pecking order theory expresses that large firms are more successful because they must have more cash after controlling their investment (Kafayat, Rehman, and Farooq, 2014). However, as a preventive motive, small firms also tend to save more cash than large firms (Magerakis, Gkillas, Tsagkanos, and Siriopoulos, 2020). 
There are research gaps related to the factors that impact the corporate cash holding policy which show inconsistent results. The results of the study conducted by (Kafayat et al., 2014) show that cash holding has significantly affected by leverage, while the results of the study conducted by Ogundipe, Lawrencia, and Ogundipe (2012) show a positive effect. However, it is different from the results of research conducted by Wijaya, Bandi, and Hartoko, (2010); and Marfuah and Zulhimi (2015) which found that cash holding has been negatively affected by leverage.

Other studies using the networking capital variable have been conducted by Kafayat et al., (2014); and Marfuah and Zulhimi (2015) with the findings indicating that networking capital has a positive impact on cash holding. It is different from the results of other studies conducted by Arfan et al., (2017) which show net working capital has an insignificant effect on cash holding. Another gap is also found in the results of the study on the effect of firm size on cash holding. The results of the study conducted by Kafayat et al., (2014) show a positive effect, while the results of the study conducted by Anjum and Malik (2013) show a negative effect.

To deal with this, the goal of this research was to see how leverage, net working capital, and firm size affected cash holdings. Because there is a research gap, academics are looking into the effect of leverage, net working capital, and firm size using different units of study, such as manufacturing firms listed on the Indonesia Stock Exchange.

\section{RESEARCH METHODOLOGY}

The unit of analysis in this study is manufacturing firms listed on the Indonesia Stock Exchange for the period 2012-2014. Data were obtained from the Indonesia Capital Market Directory (ICMD) and www.idx.co.id with the observational years in 2012, 2013, and 2014. The data collection method employed in this research is documentation. The time horizon is a combination of cross-sectional and longitudinal studies (time series). Because the number of companies studied during the study period was different, the data used was unbalanced panel data or pooled data.

Meanwhile, the target population is selected based on criteria, namely manufacturing firms that publish their complete financial reports and in rupiah currency during the observation period (2012-2014). Based on these criteria, the number of the target population in this study was 278 observations. The analysis method used in this research is panel data regression analysis. The regression model selection is necessary to determine the appropriate estimation model for use in panel data regression analysis. The tests used were the chow 
test is directed to choose the most appropriate model between common effect and fixed effect. Moreover, the Hausman test is utilized to choose the most appropriate model between the fixed effect model and the random effect model. The method for the two tests is as per the following:

1. Chow Test (Common Effect with Fixed Effect Test)

$\mathrm{H}_{0}$ : Model follows the common effect.

$\mathrm{H}_{1}$ : Model follows the fixed effect.

Decision: reject $\mathrm{H}_{0}$ if the probability value $<0,05$.

Conclusion: If $\mathrm{H}_{0}$ is rejected, the fixed-effect model is superior to the random effect model.

2. Hausman Test (Fixed Effect with Random Effect Test)

$\mathrm{H}_{0}$ : The model follows a random effect.

$\mathrm{H}_{1}$ : The model follows a fixed effect.

Decision: reject $\mathrm{H}_{0}$ if the probability value $<0,05$.

Conclusion: If $\mathrm{H}_{0}$ is rejected, the fixed-effect model is better than the random effect model.

The board information of the panel data regression equation model in this examination can be depicted as follows:

$$
C H_{i t}=\alpha+\beta_{1} L E V_{i t}+\beta_{2} N W C_{i t}+\beta_{3} S I Z E_{i t}+e_{i t}
$$

Explanation:

$\mathrm{CH}_{\mathrm{it}} \quad=$ Indicator used to measure cash holding

$\alpha \quad=$ Constant

$\beta_{1}, \beta_{2} \beta_{3}=$ Regression coefficient

$L E V_{i t} \quad=$ Indicator used to measure leverage of firm $i$ for year $t$

$N W C_{i t} \quad=$ Indicator used to measure net working capital of firm i for year $\mathrm{t}$

$S I Z E_{i t} \quad=$ Indicator used to measure size of firm $i$ for year $t$

$e_{i t} \quad=$ epsilon (error term)

Research variables used in this studt are Cash Holding $(\mathrm{CH})$, Leverage (LEV), Net Working Capital (NWC) and Firm Size (SIZE). Varible cash holding in this study is measure using the following formula (Ogundipe, Lawrencia, and Ogundipe, 2012):

Cash Holding $=($ Cash \& Cash Equivalents $) /($ Total Assets $)$ 
In this study, financial leverage is used which involves the use of funds obtained from debt or issuing preferred stocks. The use of these funds incurs a fixed cost, namely interest or dividends. Interest and preferred stock dividends are fixed financial costs that must be paid regardless of the firm's profit rate. In debt financing, the interest rate used is a fixed interest rate. The debt used is generally a long-term debt or a bond.

This study focuses on the debt ratio (debt to total assets) which shows the share of the total fund requirement that is spent with debt or the portion of the assets used to guarantee the debt. Afza and Adnan (2007) measure the level of firm leverage using the following formula:

$$
L E V=\frac{\text { total debt }}{\text { (total assets }- \text { cash and equivalent) }}
$$

Variable net working capital is the most important part in the firm's operational activities and is the main key in covering business debt, namely the ability to pay the debt which must be immediately fulfilled with current assets or what is called the current ratio, because in terms of covering business debt, definitely, it is related to assets which is part of networking capital. Therefore, the firm must be able to maintain a minimum amount of net working capital. The amount of networking capital owned by a firm can be measured using the following formula:

NWC $=($ Current Assets-Current Liabilities $) /($ Total Assets $)$

Variable firm size is estimated as a log of value of equity toward the finish of the base year which has a positive and critical relationship with the likelihood of operational activity and asset restructuring. This relationship may mirror a predisposition towards small firms as far as the accessibility of public data. It can likewise be impacted by the way that bigger firms regularly work in various business lines and geographic districts, so they are better at rebuilding the firm before the disappointment happens, while the chance of restructuring assets of small firms is more restricted.

Firm size is proxied by the natural $\log$ of total assets, the goal is to reduce the significant difference between large and small firm sizes so that total asset data can be normally distributed (Sari, 2012). Measurement of firm size is carried out using the following formula:

Size $=\log ($ Total Assets $)$ 


\section{RESULT AND DISCUSSION}

The descriptive statistics for each variable in this study can be seen in table 1, while the average cash holding of manufacturing companies can be seen in figure 1 .

Table 1. Descriptive Statistics

\begin{tabular}{lcccc}
\hline \multicolumn{1}{c}{ Variable } & $\begin{array}{c}\text { Minimum } \\
\text { Value }\end{array}$ & $\begin{array}{c}\text { Maximum } \\
\text { Value }\end{array}$ & $\begin{array}{c}\text { Average } \\
\text { Value }\end{array}$ & $\begin{array}{c}\text { Standard } \\
\text { Deviation }\end{array}$ \\
\hline Leverage & 0,039 & 2,383 & 0,519 & 0,271059 \\
Net Working Capital & $-0,639$ & 0,860 & 0,198 & 0,238228 \\
Firm Size & 10,655 & 14,330 & 12,181 & 0,678560 \\
Cash Holding & 0,003 & 0,500 & 0,092 & 0,107549 \\
\hline
\end{tabular}

\section{Avarege of Cash Holding}

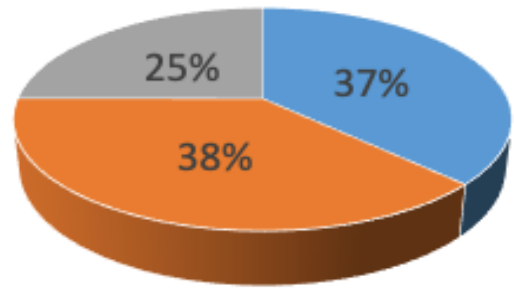

- Small Firms - Medium Firms = Large Firms

Figure 1. Average Cash Holding of Manufacturing Firms in 2012-2014

Source: Data Processed (2020)

\section{Classical Assumption Test Results}

\section{Normality Test Results}

Normality test results can be seen in figure 2 .
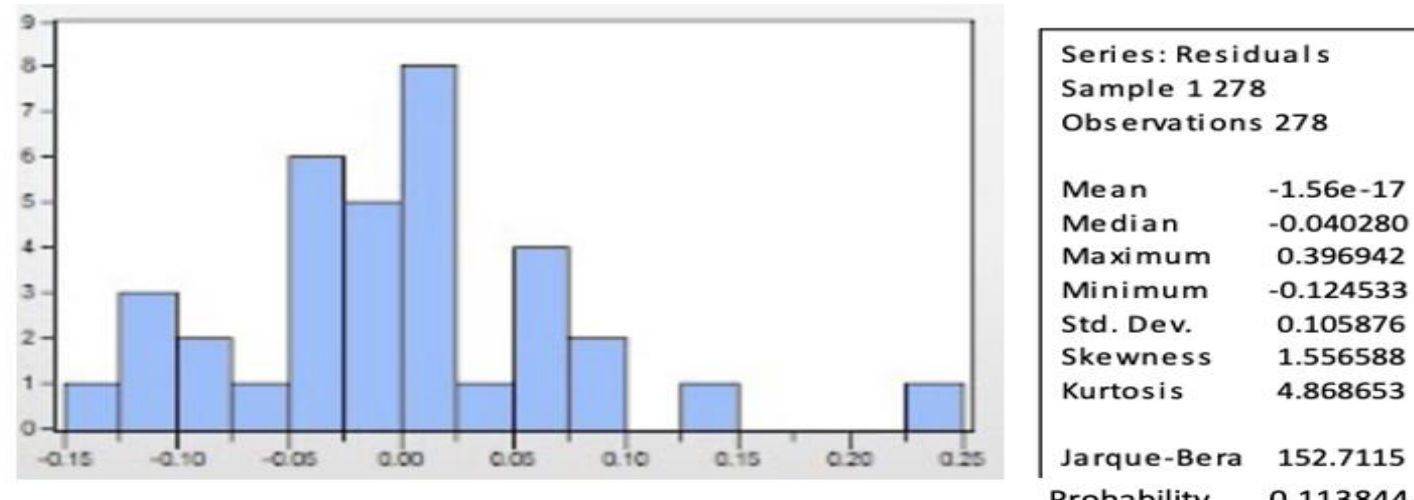

Figure 2. Normality Test Results

Source: Data Processed (2020) 
Based on figure 2, it is known that the results of the residual normality test above are: the jarque fallow value of 152,7115 with a $\mathrm{p}$ value of 0,113844 where $>0,05$ so that it accepts $H_{0}$ or which means the residuals are normally distributed.

\section{Multicollinearity Test Results}

The multicollinearity test aims to determine whether there is a correlation between the independent variables in the regression model. The results of the multicollinearity test can be seen in table 2.

Table 2. Multicollinearity Test Results

\begin{tabular}{cccc}
\hline \hline Variable & $\begin{array}{c}\text { Coefficient } \\
\text { Variance }\end{array}$ & $\begin{array}{c}\text { Uncentered } \\
\text { VF }\end{array}$ & $\begin{array}{c}\text { Centered } \\
\text { VF }\end{array}$ \\
\hline \hline LEV & 0.000699 & 5.787323 & 1.228351 \\
NWC & 0.000887 & 2.089034 & 1.230894 \\
SIZE & $8.88 E-05$ & 324.1094 & 1.005527 \\
C & 0.013493 & 331.0003 & NA \\
\hline \hline
\end{tabular}

Source: Data Processed (2020)

Based on the results of the multicollinearity test in table 2, it is known that there is no independent variable that has a tolerance value of less than 0,10 and a VIF value greater than 10. This means that the three independent variables do not have multicollinearity.

\section{Heteroscedasticity Test Results}

Heteroscedasticity testing in this study was carried out with the white test. The presence or absence of heteroscedasticity can be known from the probability value of Breusch-Pagan Godfrey which will be compared with the level of significance. If the significance probability value is above 0,05 , it can be concluded that there is no heteroscedasticity. As for the results Heteroscedasticity testing is shown in table 3 below.

Table 3. Heteroscedasticity Test Result

Heteroskedasticity Test: Breusch-Pagan-Godfrey

Null hypothesis: Homoskedasticity

\begin{tabular}{llll}
\hline \hline F-statistic & 1.530429 & Prob. F(3,274) & 0.2069 \\
Obs ${ }^{\star}$ R-squared & 4.581543 & Prob. Chi-Square(3) & 0.2051 \\
Scaled explained SS & 8.609007 & Prob. Chi-Square(3) & 0.0350 \\
\hline \hline
\end{tabular}

Source: Data Processed (2020) 
Based on table 3, it is known that the p-value of 0,2051 which is greater than 0,05 means that we do not reject $H_{0}$ which states that there are no symptoms of heteroscedasticity in the tested regression model. Thus, based on the results of the residual heteroscedasticity test, the assumptions of the regression model that do not allow for heteroscedasticity are met.

\section{Autocorrelation Test Results}

The autocorrelation test aims to test whether in the linear regression model there is a correlation between the confounding error in period $t$ and the confounding error in period $t-1$ or the previous period. In this study, the Durbin-Watson test was tested to determine the presence or absence of autocorrelation. The results of the autocorrelation test can be seen in table 4 .

Table 4. Autocorrelation Test Result

\begin{tabular}{ccccc}
\hline \hline \multicolumn{1}{c}{ Variable } & Coefficient & Std. Error & t-Statistic & Prob. \\
\hline LEV & -0.136291 & 0.099778 & -1.365938 & 0.1731 \\
NWC & $-6.23 E-05$ & 0.022449 & -0.002775 & 0.9978 \\
SIZE & 0.254765 & 0.025752 & 9.893093 & 0.0000 \\
\hline \hline R-squared & 0.014569 & 0.008065 & 1.806362 & 0.0720 \\
Adjusted R-squared & 0.310059 & Mean dependent var & 0.091723 \\
S.E. of regression & 0.302505 & S.D. dependent var & 0.107549 \\
Sum squared resid & 0.089821 & Akaike info criterion & -1.967722 \\
Log likelihood & 2.210558 & Schwarz criterion & -1.915526 \\
F-statistic & 277.5134 & Hannan-Quinn griter. & -1.946782 \\
Prob(F-statistic) & 41.04510 & Durbin-Watson stat & 2.129993 \\
\hline \hline
\end{tabular}

Source: Data Processed (2020)

Based on the Durbin-Watson table with values of $k=3$ and $n=278$, the $d L$ value is 1,78970 and $\mathrm{dU}$ is 1,81123 . The results of the autocorrelation test in table 4 obtained the Durbin Watson (DW) value of 2,129993, it is proven that the value of $\mathrm{dU}<\mathrm{dw}<4-\mathrm{dU}$ or $1,78970<2,129993<4-1,81123$ so it can be concluded that this regression model free from autocorrelation.

\section{Selection of Estimation Model}

The selection of the estimation model that has been done through the Chow test and the Hausman test are summarized in table 5.

Table 5. Estimation Model Election Results

\begin{tabular}{lll}
\hline Model Selection & \multicolumn{1}{c}{ Test Results } & Summary \\
\hline Chow Test & Value of Prob. 0,8768>0,05 & $\begin{array}{l}\text { Common Effect is more precise } \\
\text { than Fixed Effect }\end{array}$
\end{tabular}

Source: Data Processed (2020) 
Table 5 shows the results for the Chow test. The value of probability $=0,8768$, which leads to the rejection of the null hypothesis because the value is more than 0,05 and the use common effect model is more appropriate than the fixed effect.

\section{Hypothesis Testing Results}

The results of panel data regression can be seen in table 6 .

Table 6. Panel Data Regression Testing Results

\begin{tabular}{lllll}
\hline Variable & Coefficient & Std. Error & t-Statistic & Prob. \\
\hline Constanta & $-0,136291$ & 0,099778 & $-1,365938$ & 0,1731 \\
Leverage & 0,0000623 & 0,022449 & $-0,002775$ & 0,9978 \\
Net Working Capital & 0,254765 & 0,025752 & 9,893093 & 0,0000 \\
Firm Size & 0,014569 & 0,008065 & 1,806362 & 0,0720 \\
R-squared & 0,310059 & Durbin-Watson Stat & 2,129993 \\
Adjusted Rsquared & 0,302505 & & & \\
F-statistic & 41,04510 & & & \\
Prob (F-statistic) & 0,0000 & & & \\
\hline Source Dat Process & & & &
\end{tabular}

Source: Data Processed (2020)

\section{The Effect of Leverage on the Firm's Cash Holding}

The hypothesis of the effect of leverage on cash holding is formulated as follows: $\mathrm{H}_{\mathrm{a} 2}: \beta_{1} \neq 0$; leverage affects the corporate cash holding.

Based on table 6 , the value of the regression coefficient of the effect of leverage on cash holding is 0,0000623 . This value indicates that $\beta_{1} \neq 0$ so that $\mathrm{H}_{\mathrm{a} 2}$ is accepted. In other words, it can be said that leverage has a positive effect on the firm's cash holding. Each $1 \%$ increase in leverage will increase cash holding by 0,0000623\%, assuming the variables of net working capital and firm size are constant.

Based on the results of testing the second hypothesis, it is found that cash holding is positively affected by leverage with a regression coefficient value of 0,0000623 . This positive effect of leverage and cash holding designates that cash increases when leverage increases too. This finding supports the Agency theory which states that companies with high levels of leverage find it difficult and expensive to obtain additional funds or renegotiate existing debt, so the company is more encouraging to hold larger cash (Ogundipe, Lawrencia, and Ogundipe, 2012).

The results of this study are in line with the results of a study conducted by Ogundipe, Lawrencia, and Ogundipe (2012) which state that leverage has a positive effect on cash holding. However, it is in contrast with a study conducted by Wijaya et al., (2010); Marfuah 
and Zulhimi, (2015); and Jamil et al., (2016) which cash holding is negatively affected by leverage.

\section{The Effect of Net Working Capital on Firm's Cash Holding}

The following is the hypothesis for the influence of networking capital on cash holding:

$\mathrm{H}_{\mathrm{a} 3}: \beta_{2} \neq 0$; net working capital affect the corporate cash holding.

Based on table 6, the value of the regression coefficient of the effect of net working capital on cash holding is 0,25476 . This value indicates that $\beta_{2} \neq 0$ so that $\mathrm{H}_{\mathrm{a} 3}$ is accepted. Thus it can be said that the corporate cash holding is positively affected by net working capital. Each $1 \%$ increase in net working capital will increase cash holding of $0,25476 \%$, assuming the leverage and firm size variables are constant.

Based on the results of the third hypothesis testing, it is found that cash holding is positively affected by networking capital with a regression coefficient value of 0,25476 . This positive effect shows that the bigger the net working capital, the bigger the firm holds cash (cash holding). This positive result is probably existent because cash is part of networking capital, so when cash increases, networking capital also increases. In addition, current assets other than cash cannot be used as a substitute for cash at any time (Marfuah and Zulhimi, 2015). In some special situations (for example during a crisis), current assets cannot be easily converted into cash. Therefore, firm managers usually make cash reserves to maintain liquidity. This is very important because if an economic shock occurs, cash and current assets can save the firm from the threat of bankruptcy (Jinkar, 2013).

The results of this study are in line with the results of study conducted by Kafayat et al., (2014); and Marfuah and Zulhimi (2015) which state cash holding has a significantly affected on net working capital. The results of this study are slightly different from the results of a study conducted by Kim et al., (2011) which found that firms with large networking capital generally hold small amounts of cash, meaning that networking capital has a negative effect on cash holding.

\section{The Effect of Firm Size on Firm's Cash Holding}

The hypothesis of the effect of firm size on cash holding is formulated as follows: $\mathrm{H}_{\mathrm{a} 4}: \beta_{3} \neq 0$; firm size affects the firm's cash holding.

Based on table 6, the value of the regression coefficient of firm size effect on cash holding is 0,014569 . This value shows that $\beta_{3} \neq 0$ so that $\mathrm{H}_{a 4}$ is accepted. It means that firm size positively affects on cash holding. Each $1 \%$ increase of firm size, will result in an 
increase of cash holding of $0,014569 \%$, assuming the leverage and net working capital variables are constant.

In view of the results of testing the fourth hypothesis, it is found that firm size positively effects on cash holding of 0,014569 . The positive relathionship between firm size and cash holding designates that cash increases when firm size increases too. The results of this study are in line with the pecking order theory which states that large firms are more successful because they have to have more cash after controlling their investments (Kafayat et al., 2014). The results of this study are also in line with the results of a study conducted by Khalil and Ali, (2015); Ali, Ullah, and Ullah (2016); Bigelli and Vidal (2009); Kafayat et al., (2014); Shabbir, Hashmi, and Chaudhary (2016); and Tahir, Quddus, Kahnum, and Usman (2015) which states that cash holding has had a significant affected by firm size.

\section{CONCLUSIONS, IMPLICATIONS, LIMITATIONS AND RECOMMENDATIONS}

The research was conducted on manufacturing listed companies at Indonesia Stock Exchange to explore the determinants of cash holding. The empirical results showed that leverage, net working capital, and firm size have a positive effect on cash holding of manufacturing companies listed on the Indonesia Stock Exchange.

The implication of this study is that the corporation should pay close attention to its leverage and net working capital levels in order to maintain an ideal level of cash on hand. The leverage ratio can also be used to assess the determinants of cash holding in manufacturing organizations, while firm size can be used to investigate the cash holding criteria of small and larger companies.

One obvious limitation of this study is only using data of manufacturing companies as the sample. Another potential weakness is the failure to address how other factors and macroeconomic conditions, such as inflation and GDP growth, affect cash holdings. Hopefully, this study presented insights to managers, financial management consultants, shareholders, and investors.

\section{BIBLIOGRAPHY}

Ali, S., Ullah, M., and Ullah, N. (2016). Determinants of Corporate Cash Holdings: A Case of Textile Sector in Pakistan. International Journal of Economics \& Management Sciences, 5(3), 1-10.

Anjum, S., \& Malik, Q. A. (2013). Determinants of Corporate Liquidity - An Analysis of Cash Holdings. IOSR Journal of Business and Management, 7(2), 94-100. 
Arfan, M., Basri, H., Handayani, R., Shabri, M., Fahlevi, H., and Dianah, A. (2017). Determinants of Cash Holding of Listed Manufacturing Companies in The Indonesian Stock Exchange. DLSU Business and Economics Review, 26(2), 1-12.

Bigelli, M., and Vidal, F. J. S. (2009). Cash Holdings in Private Firms.

Gill, A., and Shah, C. (2012). Determinants of Corporate Cash Holdings: Evidence from Canada. International Journal of Economics and Finance, 4(1), 70-79.

Ginglinger, E., and Saddour, K. (2007). Constraints Cash Holdings, Corporate Governance and Financial Constraints, 1-33.

Jamil, S., Anwar, A., Afzaal, N., Tariq, A., and Asif, M. (2016). Determinants of Corporate Cash Holdings: Empirical Analysis of Pakistani Firms. IOSR Journal of Business and Management, 7(3), 29-35.

Jinkar, R. T. (2013). Analisa Faktor- Faktor Penentu Kebijakan Cash Holding Perusahaan Manufaktur di Indonesia. Minieconomica, 42, 129-146.

Kafayat, A., Rehman, K. U., and Farooq, M. (2014). Factors Effecting Corporate Cash Holding of Non-Financial Firms in Pakistan. Acta Universitatis Danubius. Economica, 10(3), 35-41.

Khalil, S., and Ali, L. (2015). The Effect of Family Ownership on Cash Holdings of the Firm (Karachi Stock Exchange). International Journal of Academic Research in Business and Social Sciences, 5(6), 133-141.

Kim, J., Kim, H., and Woods, D. (2011). International Journal of Hospitality Management Determinants of corporate cash-holding levels: An empirical examination of the restaurant industry. International Journal of Hospitality Management, 30(3), 568-574.

Magerakis, E., Gkillas, K., Tsagkanos, A., and Siriopoulos, C. (2020). Firm Size Does Matter: New Evidence on the Determinants of Cash Holdings. Journal of Risk and Financial Management, 13(8), 163.

Marfuah, dan Zulhimi, A. (2015). Pengaruh Growth Opportunity, Net Working Capital, Cash Conversion Cycle dan Leverage terhadap Cash Holding Perusahaan. Jurnal Ekonomi dan Pembangunan OPTIMUM, 5(1), 32-43.

Null, R., and Pathak, R. (2019). Corporate Cash Holding During Crisis and Beyond: What Matters The Most. International Journal of Managerial Finance, 15(4), 492-510.

Ogundipe, Lawrencia, and Ogundipe, A. (2012). 111 1. Journal of Business, Economics and Finance, 1(2), 1-25.

Shabbir, M., Hashmi, S. H., and Chaudhary, G. M. (2016). Determinants of Corporate Cash Holdings in Pakistan. International Journal of Organizational Leadership, 5, 50-62.

Simanjuntak, S. F., dan Wahyudi, A. S. (2017). Faktor-Faktor yang Mempengaruhi Perilaku. Jurnal Bisnis dan Akuntansi, 19(1), 25-31.

Subramaniam, V., Tang, T. T., Yue, H., and Zhou, X. (2011). The Theory of Corporate Finance. The Theory of Corporate Finance, 17(3), 759-771.

Tahir, S. H., Quddus, A., Kahnum, Z., and Usman, M. (2015). Determinants of Cash Holding Decision: Evidence from Food Industry of Determinants of Cash Holding Decision: Evidence from Food Industry of Pakistan. In Proceedings of the 27th International Business Information Management Association Conference - Innovation Management and Education Excellence Vision 2020: From Regional Development Sustainability to Global Economic Growth, IBIMA 2016, 3032-3039.

Wijaya, A. L., Bandi, dan Hartoko, S. (2010). Pengaruh Kualitas Akrual dan Leverage terhadap Cash Holding Perusahaan. Jurnal Akuntansi dan Keuangan Indonesia, 7(2), $170-186$. 